\title{
TRE ASIAN DERIVATIVE MARKETS: RESEARCH ISSUES
}

\author{
Shamsher M. and Taufiq H. \\ Universiti Putra Malaysia
}

\begin{abstract}
Theory suggests that the introduction of derivative market in a market with spot trading completes the market-based price discovery process. There are 19 derivative markets in Asia. Derivative trades in such markets help to hedge away the risk of price changes in the spot markets at very low costs. Commodity futures instruments are also needed to hedge away price changes in real sector just as financial futures does this function for the financial sector. In this paper, we examine the current status of selected commodity and financial derivative markets in Asia. It suggests that the more industrial/advanced economies have developed liquid commodities markets, and few of them have also developed active financial derivative markets. But for most of the 19 or so emerging markets in Asia, the development of derivative markets is still at an early stage.
\end{abstract}

JEL Classification: E44 \& G15

Key words: Derivative markets, Futures markets, Price risk, Commodities futures, Asian markets.

\section{Introduction}

The development of the modern day auction markets for shares and bonds in spot markets can be traced to financial developments in the early $20^{\text {th }}$ Century in the then industrial economies. Commodity futures markets also developed in parallel that was needed for the management of price changes in commodities heavily demanded in industrial economies of the last century. Modern finance theories suggest that sufficiently well-structured and price-efficient spot and futures markets are necessary for providing funds needed for economic development of any country and for risk transfer emanating from price risk, the so-called basis risk when prices of assets change over time ahead of their usage. 
Such markets help to price the risk of capital usages, and also provide means to transfer risk in derivative trading be it in the real sector or the financial sector. Efficient capital raising and allocation of financial resources are an integral part of economic development. It is now well established that securities markets, particularly the derivative markets, are not casinos but are essential for the orderly growth and development of sustainable economic activities since the contracts traded in such markets enable economic agents to manage price risk. Markets also fulfill the essential role for improving corporate governance, disclosure standards, transparency in the market place and to spur accounting standards development.

The creation of a global financial system has made the risks of a contagion and systemic failures much more likely. The impact of the Asian Financial Crisis - 1997-98 - was felt far beyond Asia, which provides evidence of greater integration of world financial markets. Integration of global capital markets, particularly emerging markets, requires greater uniformity of legal, regulatory, and operational procedures. Capital market, especially in an emerging economy, is undergoing rapid transformation, brought about by both technological innovations and globalization of the market place.

Market capitalization and trading volume of emerging markets have increased significantly during the last 15 years. World market capitalization increased almost nine times from $\$ 3.38$ trillion (1993) to $\$ 26.52$ trillion 1998 to a figure close to 35 trillion estimated for 2006; for the US markets, it increased seven fold from $\$ 1.90$ trillion to $\$ 12.93$ trillion. The most dramatic increase was that of 23 -fold growth for developing markets from $\$ 0.083$ trillion to $\$ 1.91$ trillion (see Table 1) for emerging markets. The rise in trading volume provides evidence of increased liquidity in the markets and increased necessity of risk management in these markets.

Table 1: Capitalization and trading volume of World, US and emerging markets

\begin{tabular}{l|c|c|c|c|c|c}
\hline & \multicolumn{3}{|c|}{ Market Capitalization (\$US billion) } & \multicolumn{3}{|c}{ Trading Volume (\$US billion) } \\
\hline & World & US & Emerging & World & US & Emerging \\
\hline 1983 & 3384 & 1898 & 83 & 1228 & 797 & 25 \\
1984 & 6513 & 2637 & 135 & 3574 & 1796 & 78 \\
1985 & 11713 & 3506 & 755 & 7468 & 2016 & 1170 \\
1986 & 10922 & 4485 & 1000 & 4783 & 2082 & 631 \\
1987 & 17782 & 6858 & 1974 & 10216 & 5091 & 1047 \\
1988 & 26520 & 12926 & 1908 & 22874 & 13149 & 1957 \\
2006 & & & & & & \\
\hline
\end{tabular}

Source: Aggarwal R., (2001). McDonough School of Business, Georgetown University. 
The growth in emerging markets has been due to several factors, including privatizations, participation of foreign institutional investors, increase in the domestic investor base, and increased initial public offers, IPOs, in these markets. Put simply, nations are taking steps to lower the cost of capital to spur economic activities by fast-tracking financial market development for share and bond trading.

However, emerging markets now need to start addressing second-generation capital market development issues. These are: developing financial intermediaries that have professionals with financial sector skills; enhancing domestic institutional investor base in addition to foreign investors; providing self-regulatory organizations; and developing mechanisms for investor protection. More importantly, risk management at all levels of the financial structure is extremely important, but is severely lacking in emerging markets due first to the scarcity of derivative instruments and second, where the derivative markets are already functioning, because of failure to generate liquidity. This is the subject of this paper to provide an overview to the Asia's status of derivative market development.

There are about 55 organized derivative exchanges in the world for trading some 112 financial derivatives while there are 95 spot markets trading some 150,000 common stocks and unknown number of bond listing. Parallel to this is the long-established commodity markets that have existed for almost 100 years especially in the industrial economies. In Asia, the developed economies (Hong Kong, Japan, Korea, and Singapore) have developed viable financial derivative markets during the post-1980s. Some emerging markets (India, Malaysia, and Thailand) have also organized in the 1990s fast-developing financial derivative markets for interest rates, currency, futures and options. Derivative market process (commodity as well as financial derivative) plays an important role for managing systematic risk in the market place. Developed economies have nurtured commodity futures over more than a hundred years that assists even today to transfer the price-change risk (basis risk) to willing parties to bear these risk.

Similarly, since 1972, trading in financial derivatives in some 35 large and efficient derivative markets in developed countries has become liquid, and pricechange risk of financial assets are transferred effectively to willing parties at very low costs of about $0.5-1$ percent. As for the Asian derivative markets, these have mixed experience even in the second largest economy, Japan, and are severely underdeveloped in several emerging markets while some of them are very liquid. The attitude of regulators is also quite discouraging for the nurturing of derivative markets, given the volatility and high-profile cases of failures of derivative hedge activities in several Asian countries, which have increased the political costs of promoting such markets because of the bad publicity from these cases. 
The lessons to be learned from several such failures in emerging markets are not clearly and cogently analyzed, thus further adding to the bad public perception of the need for derivative markets. Because each failure has its own peculiar characteristics it is difficult to provide standardized reasons for failures of all cases. Commodity futures have been around for a long time to address the issue in agricultural and industrial sectors. However financial derivative are recent developments and the regional financial derivative landscape has changed dramatically in the years since 1997 .

The rest of the paper is organized as follows. In sections 2 to 6 , we describe the evolution of futures markets in selected Asian countries. The main theme is to draw some conclusions about the organization, trade, size and liquidity of these markets from an analysis of 6 selected markets. The chapter ends with a discussion in Section 8.

\section{Indian commodity and futures markets}

Agriculture is a significant sector in which 70 percent of India's population finds a living. The commodity futures market in today's more industrial India is almost as old as in the US and UK. The Indian experience, however, is much older as references to such markets can be traced to Kautilya's Arthasastra, a document dating at least two millenia. The first organized futures market in modern history was established in 1875 as the Bombay Cotton Trade Association trading in cotton futures contracts. Oil seeds and food grains contracts followed soon. A large number of commodity exchanges trading futures contracts in several commodities like cotton, groundnut, groundnut oil, raw jute, jute goods, castor seed, wheat, rice, sugar, precious metals like gold and silver were flourishing throughout the country in the first half of the $20^{\text {th }}$ Century. Futures trading was prohibited during the Second World War. After 1947, especially in the second half of the 1950s and the first half of 1960s, commodity futures trading picked up. However, due to persistent shortages of real commodities during the early and mid-sixties due to the governments till then focusing on industrializing the country, futures trading in most of the commodities was prohibited.

Considering the importance of agriculture in India's GDP and the genuine requirements of promoting sound commodity futures markets in the country, a number of major reforms have been undertaken since the early 1990s. In this regard, the most important changes that have taken place in the commodity area were the removal of prohibition on futures trading in a large number of commodities and the facilitation of setting up of modern, de-mutualised exchanges by the government of India. These two initiatives together have spurred commodity futures markets in terms of both participation and standards of practices. 
However there are still a number of obstacles in fully exploiting the opportunities available due to lack of knowledge and accessibility of traders to the market. Liquidity constraint is one of the major problems of the Indian commodity futures market. There are many commodity futures exchanges, which are small in size and face liquidity problem. Due to this, the market participants, especially hedgers, are not able to trade in these commodity exchanges. According to Mansing (2004) the removal of restrictions on regional commodity exchanges, which are functioning in a fragmented and disorganized way, are important to achieve greater volumes in trading.

The financial futures trading in the two key financial markets is found in Bombay and in Kulkata. For some decades, a form of futures contract (badla) was traded in these markets, which was briefly banned for several years. Badla, with minor changes have been reintroduced in the year 2000, and is providing share-based hedging activities, a resurgence of interest. Other new instruments are also traded, but the futures trading is not that well developed.

Badla is an indigenous carry-forward system invented on the Bombay Stock Exchange as a solution to the perpetual lack of liquidity in the secondary market. Trading involved buying stocks with borrowed money with the stock exchange acting as an intermediary at an interest rate determined by the demand for the underlying stock and a maturity not greater than 70 days. Like a traditional futures contract, badla is a form of leverage; unlike futures, the broker-not the buyer or seller-is responsible for the maintenance of the market-to-market margin.

Badla contracts were banned by the o "Stock Exchange Board of India" Stock Exchange Board of India (SEBI) in 1993 effectively from March 1994,

Table 2: Exchange value of trading of Indian commodity futures

\begin{tabular}{|c|c|c|}
\hline & \multicolumn{2}{|c|}{ (In Rupees Crores)* } \\
\hline Name of the Exchange & $2000-2001$ & $2003-2004$ \\
\hline $\begin{array}{l}\text { The Indian Pepper and Spice Trade } \\
\text { Association, Kochi }\end{array}$ & 2834 (\$629 million) & $\begin{array}{l}585.51(\$ 130 \\
\text { million) }\end{array}$ \\
\hline $\begin{array}{l}\text { The Ahmedabad Commodity Exchange, } \\
\text { Ahmedabad }\end{array}$ & 806 ( $\$ 180$ million $)$ & $\begin{array}{l}5585.07(\$ 1241 \\
\text { million) }\end{array}$ \\
\hline National Board of Trade, Indore & - & $\begin{array}{c}53013.69 \\
(\$ 11780 \text { million })\end{array}$ \\
\hline The Chamber of Commerce, Hapur & 2166 & 5672.05 \\
\hline Vijai Beopar Chamber Ltd, Muzaffarnagar & 9518 & 2872.00 \\
\hline $\begin{array}{l}\text { The National Multi Commodity Exchange } \\
\text { of India Ltd, Ahmedabad }\end{array}$ & - & 23840.30 \\
\hline $\begin{array}{l}\text { Surendernagar Cotton Oil and Oilseeds } \\
\text { Association Ltd, Surendemagar }\end{array}$ & - & 20913.93 \\
\hline Haryana Commodities Ltd., Hissar & - & 3036.55 \\
\hline $\begin{array}{l}\text { National Commodity and Derivative } \\
\text { Exchange Ltd, Mumbai }\end{array}$ & - & 1490.25 \\
\hline
\end{tabular}

Notes: There are several other commodity futures exchange but their size is very small and these are facing liquidity problems. * 1 USD $=45$ Rupees; 10 Crores equal million. 
amid complaints from foreign investors as promoting excessive speculation, with the expectation that it would be replaced by a futures-and-options exchange. After the ban took effect, trading volume on BSE fell dramatically. Statistics show (Berkman and Eleswarapu, 1998) that compared to the first two months of 1994, the average daily trading volume for Badla stocks was 72 percent lower for the period April to December 1994. However promised futures-and-options exchange was not established and badla contracts were legalized again in 1996 (with a carry-forward limit of Rs 20 crore - Rs 2 million - per broker) and banned again on July 2, 2001, following the introduction of futures contracts in 2000. The futures contracts are now shaping up, and it will take some years before these gain liquidity and hedge efficiency.

\section{Korean futures and option market}

South Korean economy is an industrial economy. Contribution of the agriculture sector in the economy is minimal. There is no dominant agricultural product, even long time before, in Korea that needed to be hedged for risk. Therefore commodity futures market is not very well known among the Korean investors. In the ten years since 1995, the trading activity on the Korea Stock Exchange, KSE, has led to huge increases in trading of derivatives. Since the KSE launched futures, Kospi 200 Index, in May 1996 and options on the stock index in July 1997, the traded volume has increased exponentially, creating huge liquidity. The options contract now ranks as one of world's biggest listed derivatives, measured in terms of both volume and value. Just eight years after the debut of these markets, the average daily volume was 210,000 futures and 11,500,000 options. More than 900 million Kospi 200 futures and options were traded in 2001. Already 1.5 billion contracts have been traded in the first half of 2002 (both sides of a transaction treated as one contract). Trading volume rose 120 percent in 2000 and 330 percent in 2001.

On a combined basis, the Kospi 200 futures and options now outrank the S\&P 500 and the Nikkei 225. According to data published by Bloomberg, the notional value of trading in the Kospi contracts was $\$ 6.9$ trillion in the first half of 2002: \$2.9 trillion was the number for S\&P 500 in the US. The Nikkei 225 futures and options were 15 times smaller in notional values and 100 times smaller in volume than the Korean equivalents. There are several key factors to be considered for this degree of success of derivative markets in Korea.

First, the root cause is the entry of households into the market. Korean traders have an appetite and an enthusiasm for trading that cannot be found anywhere else in the world. Trading in the financial market is now part of modern Korean culture, and there is a widespread knowledge of the fundamental mechanisms of the futures and options especially after the devastating financial crisis that shook the economy in the late 1990s and cost US\$ 54 billion to repair the derailed 
economy. At any time during day or night, there are educational programs on the television about technical analysis and trading strategies for stocks and derivatives. Trading the market is part of the everyday life of the people and comes as a natural behavior.

Second key factor is the small size of these contracts. In mid-October 2002, the value of a single futures contract on the Kospi 200 was approximately 42.5 million won, which at the then exchange rate was equivalent to $\$ 34,000$, making it roughly comparable in size to the E-mini S\&P 500. The options contract is even smaller, representing one-fifth of the value of the futures contract. A unique characteristic of this market is the preponderance of local retail participants. Individual investors account for two-thirds of overall trading volume.

The third key factor is the formidable penetration of the Internet in Korean society, which has allowed online trading to develop very rapidly since 1999. The number of people with Internet access rose from 1.6 million in 1997 to 10.9 million in 1999 to 24.4 million in 2001 . The number continues to grow and in 2006 there are more accounts than there are households. The ratio of online securities trading to total securities trading has followed similar pattern, moving from 1.9 percent in 1998 to 19.0 percent in 1999, 46.6 percent in 2000 and 52.3 percent in 2001. As of 2001, among the 44 local brokers, 38 were running online trading business and of these, five were exclusively online. These figures make Korea the world leader in online securities trading. One reason for the popularity of online trading is the low transaction cost.

Foreign investors have progressively increased their presence in the Kospi 200 futures and options markets. They represent currently about 7 percent of the total futures and options trading, up from 2 percent in 1999. Foreign investors include the proprietary trading desks of large European and US investment banks along with US options market makers.

For any other derivatives exchanges, volume like that would be cause for celebration. But for KFE, it is a sign that the Kospi market may be entering a new, more mature phase, with lower growth and less speculative trading. But possibly this is because of greater appreciation of the risk management aspects of futures and options. This may be seen in the wide divergence between the open and total volume, which indicates the speculative nature of the trade. Future development is more likely to be towards more hedge-interest.

\section{Hong-Kong futures and option market}

After being ceded by China to the British under the Treaty of Nanking in 1842, the colony of Hong Kong quickly became a regional centre for financial and commercial services based particularly around the Hong Kong and Shanghai Bank and merchant companies such as Jardine Matheson. In 1841, there were only 7,500 Chinese inhabitants and a handful of foreigners, but by 1859 , the 
Chinese community was over 85,000 augmented by about 1,600 foreigners. The economy was closely linked to commercial activities dominated by shipping, banking and trade of merchant companies. Gradually there was increasing diversification to services and retail outlets to meet the needs of the local population, and also shipbuilding and maintenance linked to the presence of the British naval and merchant shipping. There was some industrial expansion in the nineteenth century; notably sugar refining, cement and ice factories among the foreign sector, alongside smaller-scale local workshop manufactures. The mainland territory of Hong Kong was ceded to British rule by two further treaties in this period; Kowloon in 1860 and the New Territories in 1898.

The industrialization of Hong Kong is usually dated from the time of embargoes of the 1950s. Certainly, Hong Kong's prosperity could no longer depend on China trade. However, industry emerged in the Nineteenth century and began to expand in the inter-war periods. Nevertheless, industrialization accelerated after 1945 with the inflow of refugees from China, entrepreneurs and also capital fleeing the civil war on the mainland. The most prominent example is immigration from Shanghai,

Table 3: Trading Activities for KOSPI 200 Futures Contract from 1996-2005 (Million KRW*)

\begin{tabular}{l|c|c|c|c|c}
\hline Year & $\begin{array}{l}\text { Total Trading } \\
\text { Volume }\end{array}$ & $\begin{array}{l}\text { Daily } \\
\text { Average. }\end{array}$ & Total Value & $\begin{array}{l}\text { Daily } \\
\text { Average }\end{array}$ & $\begin{array}{l}\text { Open } \\
\text { Interest }\end{array}$ \\
\hline 1996 & 715,621 & 3,670 & $30,689,920$ & 157,384 & 4,908 \\
1997 & $3,252,060$ & 11,137 & $103,606,789$ & 354,817 & 22,765 \\
1998 & $17,893,592$ & 61,279 & $405,903,405$ & $1,390,080$ & 26,689 \\
1999 & $17,200,349$ & 69,078 & $821,408,692$ & $3,298,830$ & 38,026 \\
2000 & $19,666,518$ & 81,604 & $859,711,142$ & $3,567,266$ & 30,052 \\
2001 & $31,502,184$ & 128,058 & $1,128,613,730$ & $4,587,860$ & 42,198 \\
2002 & $42,868,164$ & 175,689 & $1,999,411,170$ & $8,194,308$ & 63,805 \\
2003 & $62,204,783$ & 251,841 & $2,677,989,766$ & $10,842,063$ & 84,837 \\
2004 & $55,608,856$ & 223,329 & $2,978,520,541$ & $11,961,929$ & 89,702 \\
2005 & $43,952,325$ & 178,756 & $3,047,530,620$ & $12,267,781$ & 83,418 \\
\hline
\end{tabular}

$1 \mathrm{USD}=936$ Korean Won.

Table 4: Trading activities for KOSPI 200 option contract from 1997-2006 (Million KRW)

\begin{tabular}{l|c|c|c|c|c}
\hline Year & $\begin{array}{l}\text { Total Trading } \\
\text { Volume }\end{array}$ & $\begin{array}{l}\text { Daily } \\
\text { Average }\end{array}$ & Total Value & $\begin{array}{l}\text { Daily } \\
\text { Average }\end{array}$ & $\begin{array}{l}\text { Open } \\
\text { Interest }\end{array}$ \\
\hline 1997 & $4,528,424$ & 31,890 & 313,045 & 2,204 & 206,904 \\
1998 & $32,310,812$ & 110,653 & 222,6770 & 7,625 & 205,764 \\
1999 & $79,936,658$ & 321,031 & $8,631,648$ & 34,665 & 383,207 \\
2000 & $193,829,070$ & 804,270 & $16,620,835$ & 68,966 & 536,818 \\
2001 & $823,289,608$ & $3,346,706$ & $47,344,221$ & 192,456 & $2,681,265$ \\
2002 & $1,889,823,786$ & $7,745,179$ & $125,227,755$ & 513,228 & $4,845,491$ \\
2003 & $2,837,724,953$ & $11,488,765$ & $159,686,524$ & 646,504 & $3,102,844$ \\
2004 & $2,521,557,274$ & $10,126,736$ & $144,689,287$ & 581,081 & $2,782,724$ \\
2005 & $2,535,201,693$ & $10,181,533$ & $140,825,407$ & 565,563 & $3,299,722$ \\
\hline
\end{tabular}

$* 1$ USD $=936$ Korean Won at end 2006. 
which created the cotton spinning industry in the colony. Hong Kong's industry was founded in the textile sector in the 1950s before gradually diversifying in the 1960s to clothing, electronics, plastics and other labor-intensive production mainly for export.

While manufacturing was moved out of the island during the 1980s and 1990s, with the rise of China as production centre, there was a surge in the service sector. This transformation of the structure of Hong Kong's economy from manufacturing to services was dramatic. ${ }^{1}$ Most remarkably it was accomplished without faltering growth rates and with an average unemployment rate of only 2.5 percent.

Since the late 1960s, Singapore and Hong Kong have been competing with each other to be the next largest international financial center after Tokyo. While Singapore had a head start in 1968 when the Asian-dollar market was first introduced, Hong Kong was lagging behind because of its moratorium on banking licenses arising from the banking crisis in 1965 (Jao, 1997). Hong Kong's privileged location in the Northeast Asia makes it a gateway to China. Moreover Hong Kong is situated at appropriate time zones that allows 24-hour continuous trading of foreign exchange and gold when the two markets in New York and London are closed. With the onset of globalization in the 1990s, Hong Kong now relies more and more on centrifugal forces for the success as international financial centre. Such forces have attracted multinational corporations to set up their operational headquarters for their funding needs, treasury operations as well as risk management.

In this regard, Hong Kong stock market was started in 1891 to accomplish the objective of international financial location for Northeast Asia and to boost economic growth. It is one of the most established stock markets in the world, classified by the International Finance Corporation (IFC) as a developed market. In Hong Kong, there is a strong presence of the world's major financial institutions: 167 foreign banks including 85 of world's top 100 banks, 323 overseas securities and commodity trading companies, 122 overseas insurers, and 1,182 unit trusts and mutual funds. Hong Kong has the second largest stock market in Asia and it is the 7th largest in the world. As at end 2006, Hong Kong market capitalization was over about US\$ 500 billion.

Therefore risk management tools (both in commodity and financial products) are well established in Hong-Kong. The Hong Kong Futures Exchange (HKFE) started as a commodity futures exchange in 1976 (formerly called Hong Kong Commodity Exchange) with modest volume. In May 1986, it shifted to index futures trading with the introduction of Hang Seng Index futures. Now the Hang Seng Index futures is the flagship product for the exchange. In March 1993, HKFE entered into option trading with the launching of Hang Seng Index options. HKFE achieved another milestone when a brand new currency futures product called the "Rolling Forex" was officially launched in November 1995.

${ }^{1}$ Economic History of Hong Kong by Catherine R. Schenk, University of Glasgow, Encyclopedia. 
HKFE has a link with the Philadelphia Stock Exchange for the trading of currency option products at HKFE during Asian trading hours. In addition, HKFE also has an agreement with the New York Mercantile Exchange to trade its precious metal and energy products in Hong Kong. On the Chinese front, HKFE maintains a close relationship with the Chinese Securities Regulatory Commission and the Chinese Commodity Exchange.

Unfortunately, the enthusiasm outstripped the risk management measures. The rudimentary state of the latter was exposed by the October 1987 stock market crash. A number of futures brokers collapsed and the government had to organize the rescue of the futures market. In subsequent years, the futures exchange built up its volume and reputation.

Table 5: Trading volume of financial derivative in Hong-Kong Exchange

\begin{tabular}{|c|c|c|c|c|c|c|c|}
\hline & 2000 & 2001 & 2002 & 2003 & 2004 & 2005 & 2006 \\
\hline $\begin{array}{l}\text { Heng Seng } \\
\text { Index Futures }\end{array}$ & $4,023,138$ & $4,400,071$ & $4,802,422$ & $4,996,057$ & $8,601,559$ & $\overline{9,910,565}$ & $12,718,380$ \\
\hline $\begin{array}{l}\text { Mini HengSeng } \\
\text { Index Futures }\end{array}$ & 120,165 & 769,886 & $1,107,964$ & $1,128,032$ & $1,457,681$ & $1,501,342$ & $2,140,242$ \\
\hline $\begin{array}{l}\text { MSCI China } \\
\text { Free Index }\end{array}$ & 0 & 3,141 & 1,869 & 300 & - & - & - \\
\hline $\begin{array}{l}\text { Hang Seng } 100 \\
\text { Futures }\end{array}$ & 30,991 & 78 & 0 & 0 & - & - & - \\
\hline $\begin{array}{l}\text { Dow Jones } \\
\text { Industrial } \\
\text { Average } \\
\text { Futures }\end{array}$ & 0 & 0 & 6,773 & 8,984 & & & \\
\hline $\begin{array}{l}\text { Red-Chip Index } \\
\text { Futures }\end{array}$ & 3,801 & 533 & 0 & 0 & - & - & - \\
\hline $\begin{array}{l}\text { Roliling Forex } \\
\text { Futures }\end{array}$ & 3279 & 4,226 & 3,053 & 0 & - & - & - \\
\hline $\begin{array}{l}\text { One Month } \\
\text { HIBOR Futures }\end{array}$ & 12,075 & 14,315 & 970 & 120 & 733 & 246 & 155 \\
\hline $\begin{array}{l}\text { Three Month } \\
\text { HIBOR Futures }\end{array}$ & 325155 & 629,491 & 280,257 & 50,729 & 58,307 & 24,935 & 13,888 \\
\hline $\begin{array}{l}\text { Three Year } \\
\text { Exchange Fund } \\
\text { Note Futures }\end{array}$ & 0 & 1,175 & 3,673 & 2,215 & 2,225 & 1,250 & 0 \\
\hline Stock Futures & 3,322 & 6,945 & 21,056 & 18,654 & 17,274 & 13,069 & 102,010 \\
\hline $\begin{array}{l}\text { Hang Seng } \\
\text { Index Option }\end{array}$ & 544,047 & 716,114 & $1,070,431$ & $2,118,792$ & $2,029,068$ & $3,071,822$ & $4,095,679$ \\
\hline $\begin{array}{l}\text { Hang Seng } 100 \\
\text { Options }\end{array}$ & 5893 & 111 & 0 & 0 & - & - & - \\
\hline $\begin{array}{l}\text { Mini Hang } \\
\text { Seng Index } \\
\text { Option }\end{array}$ & 0 & 0 & 6,176 & 32,131 & 26,882 & 30,595 & 53.456 \\
\hline Stock Option & $4,188,702$ & $4,002,655$ & $3,724,760$ & $4,220,638$ & $5,611,832$ & $8,722,393$ & $18,127,353$ \\
\hline $\begin{array}{l}\mathrm{H} \text { share index } \\
\text { futures }\end{array}$ & & & & 47,941 & $1,743,700$ & $1,978,673$ & $4,880,470$ \\
\hline $\begin{array}{l}\text { H share index } \\
\text { option }\end{array}$ & & & & & 77,758 & 257,425 & 758,247 \\
\hline
\end{tabular}

Source: Hong Kong Exchange, 2006. 
Table 5 clearly indicates that only few futures and option contract are trading with reasonably high volume. However, most of the futures and option contract are facing serious liquidity. Out of 17 contracts, only six contracts are actively traded in the Hong Kong exchange. Trading on only three contracts namely the index futures, index option and stock option steadily increased (more than 200\%) over the six year time from 2000 to 2006. However, in August 1998 the government intervened in the market due to the alleged speculation against the Hong Kong dollar. In the following month, numerous measures were introduced to restrict derivatives trading. Perhaps due to regulatory measures, trading volumes of derivative contracts in Hong Kong's exchange have not risen in line with the global growth trend. New product launches have seen limited success, and trading continues to be dominated by index futures products and stock options only.

\section{China futures and option market}

Two years after the death of Mao Zedong in 1976, it became apparent to many leaders that economic reform was necessary to move away from central planning to engage the masses in economic activities by bringing the capitalists to exploit the cheap labor supply. During his tenure as China's leader, Mao had encouraged social movements such as the Great Leap Forward and the Cultural Revolution which had had as their bases ideologies such as serving the people and maintaining the class struggle. By 1978 Chinese leaders were searching for a solution to serious economic problems inherited by Hua Guofeng, the man who had succeeded Mao Zedong, and by Deng Shiaopeng, who ousted Hua.

The issue of economic reform became politicized as the issue was used as a means by Deng to attain the leadership of the Chinese Communist Party. Therefore the initial form the new economy took was not a radical one. China was still a state in which the central government retained the dominant power in economic resource allocation and responsible local officials worked for the interest of the units under their control, as stated by an observer.

One important aspect of Chinese economic reform was the decision of China to join the world economy. Deng Xiaoping and his allies hoped to engineer this 1979 resolution in two ways: by expanding foreign trade, and by encouraging foreign companies to invest in Chinese enterprises. This policy - denoted the "Open Policy" - was a drastic departure from the policies of Mao Zedong and, in fact, from centuries of Chinese political culture.

The implementation of the Open Policy was so successful that by 1988 the leaders of the CCP were encouraged to create a new program called the coastal development strategy. Moreover, by involving more overseas investors, importing

\footnotetext{
${ }^{2}$ In this brochure China refers to the Mainland of the People's Republic of China, excluding Hong Kong SAR, Macao SAR and Taiwan region.
} 
both capital and raw materials, and exporting China's cheap excess labor power, the new policy was one of export-led growth or export-oriented industrialization. It was explicitly modeled on the experiences of Taiwan and the other Asian 'small dragons'.

Due to this reform, Chinese government started to develop the Chinese financial market from late-1990s. China's spot and futures markets ${ }^{2}$ have been developing since the $1980 \mathrm{~s}$, in tandem with the market reforms and the liberalization of the country's economy. In July 1981, issuance of Treasury bonds was resumed in China. Six years later, a secondary market for the trading of Treasury bonds was established. By the mid-1980s, enterprises started to issue corporate bonds and shares to the public. In December 1990, the Shanghai Stock Exchange and Shenzhen Stock Exchange were established. China Securities Regulatory Commission (CSRC) is the sole national securities regulatory body. It was mandated in October 1992 to regulate all of China's securities and futures markets. However, despite all these reforms, the stock exchange is a branch of the government, unlike the stock exchanges of most countries.

At present, China's securities market offers seven types of financial instruments: A shares, ${ }^{1} \mathrm{~B}$ shares, ${ }^{2}$ Treasury bonds, Treasury bond repurchases, corporate bonds, convertible bonds and securities investment funds. Initially the two stock exchanges traded bond futures in very high volumes. Unfortunately, risk management procedures were not very adequate - margins were as little as one per cent of contract price in early 1995. These difficulties came to a head in a scandal involving chaotic trading of bond futures contracts in the Shanghai Stock Exchange, one of approximately 10 exchanges trading bond futures at that time. One of largest securities firms incurred huge losses when its short-selling strategy went disastrously wrong, to the point of threatening the stability of the entire financial system. Shortly thereafter, the government shut down the bond futures markets and scaled back trading in commodity futures.

That experience has been very important in having a bearing on the reopening of any trading in financial futures contracts. Therefore no financial derivatives have been permitted since, although there is in mid-2000s discussion of a possible index futures contract. There are several factors to be discussed regarding the failure of bond futures and subsequent restriction on the introduction of financial futures. For the most part, China's futures markets are closed to foreign investors and brokerage firms. In addition, Chinese futures companies, which number around 200 or so, serve primarily as agents, and are not involved in broader business dealings. Stock and fund brokerages cannot currently participate in futures transactions. In December 2001, China Securities Regulatory Commission announced that the Shanghai Futures Exchange was preparing to launch longawaited stock index futures. But he gave no timeframe in the announcement!

${ }^{3}$ Common shares denominated in RMB.

${ }^{4}$ Domestically listed common shares quoted in US dollars or HK dollars. 
To avoid a repeat of the events in the mid-1990s, China will have to develop a stable regulatory system for its futures market backed up by vigorous enforcement. This too is an area that raises the concerns of some. According to Leong, "The infrastructure on the futures side is comparatively rudimentary on the mainland" and "Pertinent rules and law still await China Securities Regulatory Commission's formulation." In this area, Hong Kong could play a crucial advisory role, according to Katherine Wang, spokeswoman for Hong Kong's market regulator, the Securities and Futures Commission.

But in the case of commodity futures, China already is quite advanced in trading and also in regulating the market mechanism. Chinese economy traditionally is based on agriculture. Even after economic reforms, which increased industrial contribution to the GDP, the bulk of the people still depend on agricultural economy. Due to the WTO agreement (China already signed the WTO agreement in 2002) agri-product prices are subject to international competition. Therefore, Chinese regulatory authorities are keen to develop agriculture futures faster than financial futures.

The first domestic commodity futures market was Zhengzhou Grain Wholesale Market, which introduced its first futures contract based on physical delivery in October 1990. During the years 1990-93, 50 futures exchanges in China commenced operations. To put this in context, that was equivalent to almost the number of futures exchanges in the world combined. Trading volume exploded, but the same product was often traded on a number of exchanges resulting in confusion; contracts were not standardized and were often traded on unreasonable terms. The exchanges were operating without appropriate and coordinated management (in particular, risks management) systems. The market was, to say the least, disorderly.

In the October of 1994, the State Council of People's Republic of China regulated and merged these exchanges into 15 . The 15 futures exchanges were regulated again and restructured into three by the State Council in 1998. The three futures exchanges are: Shanghai Futures Exchange (SHFE), Zhengzhou Commodity Exchange (ZCE), and Dalian Commodity Exchange (DCE). Today, the futures market has three exchanges and 180 brokerage firms, compared with 50 exchanges and 1,000 brokerage firms at the peak in 1994. The traded products have been downsized from 35 to 12 products.

The FIA statistics also reflects the emergence of China as a major player in the global commodity futures market. Only two of the three commodity exchanges in the Mainland China, namely the Dalian Commodities Exchange and the Shanghai Futures Exchange, are recorded in the FIA statistics. Both exchanges showed impressive growth in 2003. The former recorded a 54.9 percent rise in its turnover while the latter more than doubled its turnover (229 percent). The Dalian Commodities Exchange even overtook the Chicago Board of Trade (CBOT) to become the third largest commodity exchange in the global ranking. 
One of the reasons for this impressive performance is due to the small size of the contracts: soybean contract is 7 percent the size of the CBOT contract for the same product. ZCE has contracts on wheat, mung bean, etc., while DCE offers contracts on soybean, soybean meal, etc. SHFE provides futures contracts on other commodities such as copper, aluminum, rubber, etc. By and large, the trading in agricultural products tends to dominate. The most actively traded products are soybean, wheat and copper.

The bar graphs in Figure 1 shows the trading summary of the futures in 2003. The increase in China's futures trading no doubt reflects the country's surging consumption of physical commodities to support its rapid economic growth. There was a period in the early 1990s, when the financial futures trading was permitted in over the counter trades. After spectacular failures of hedges in some cases, a total ban has been imposed on futures trading in financial instruments. Nevertheless, some degrees of private deals are still made in financial futures trades. No statistic is available to report on this.

China's competitive advantage to attract foreign capital for its rapidly developing economy will be lost if it does not have a risk-management instrument like financial futures. China's financial futures market was set up in 1990 and experienced a quick expansion until the mid-1990s. However, due to the loopholes in the regulatory scheme it led to irregularities like fraud and strong speculation forcing the government to close these markets. In addition, there are other barriers to reintroduce financial futures market in China. For example, the major-

Figure 1: Trading volume and turnover of Chinese futures contracts in 2003

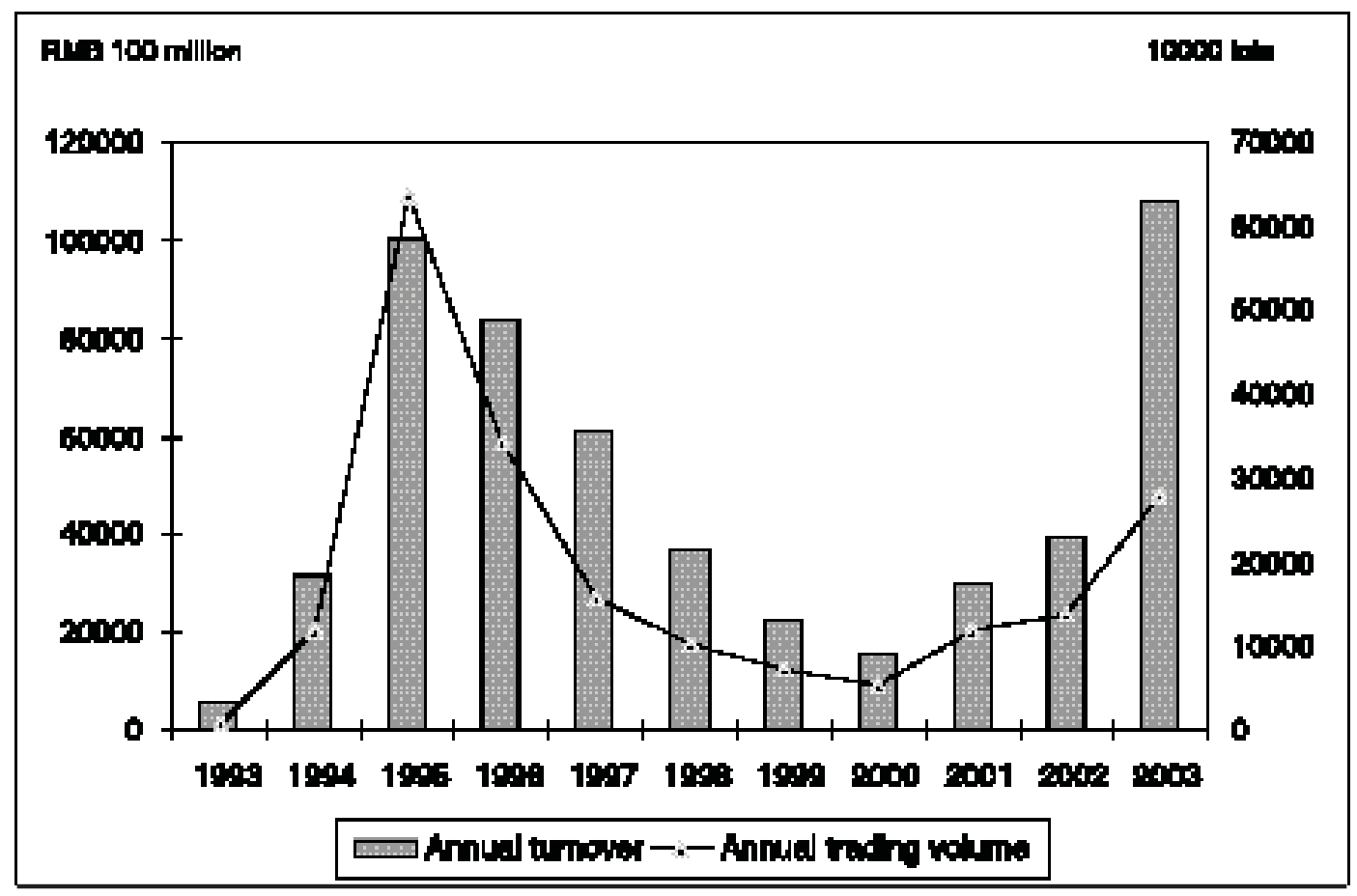

Source: China Securities Regulatory Commission, April 2004 
ity of Chinese investors do not understand the significance of the market; the relevant laws and regulations are not gazetted yet; the immaturity of China's market oriented economy need to be perfected.

\section{Malaysian futures and option market}

Malaysian futures market started in the 1980s when The Kuala Lumpur Commodity Exchange (KLCE) was organized to meet the needs for a price discovery and hedging mechanism within the region to improve the marketing efficiency of Palm Oil. The tin futures were done in London for some long time before, although most tin exports emanated in Malaysia, which failed to develop a futures market on this commodity. The first futures contract traded on the KLCE was palm oil which was launched on October 23, 1980. A rubber futures contract was introduced in 1983, which was followed by tin futures in October 1987, Cocoa in August 1988 and refined, bleached palm olein contract in February 1990. Due to the heavy short selling tactics of speculators, massive defaults followed in February and March 1984 and a series of crises led to the collapse of the three and a half year old crude palm oil futures contract.

The authorities undertook a major revamp of the exchange in 1985 to correct the structural weaknesses that were exposed in that episode. Among others, a new clearinghouse was set up and a new Commodities Trading Act, 1985, was introduced. However since 1990 (after recovery from the economic recession of 1986-89), the government changed the direction of the country's economic policy from agriculture based economy to industrial economy. As a result, most commodity investor lost their interest on futures market. Most of the commodity futures, except the Palm oil futures, could not survive. The following Table shows the trend of the all commodity futures contracts from 1989 to 1992. Table 6 clearly shows that introduction of different commodity futures failed to sustain due to liquidity constraint, except for Crude Palm oil futures contract.

Among the reasons cited for the lack of interest in the market is liquidity which caused problems when participants wanted to leave the market at the price they wanted. Another reason is the lack of government commitment due to the heavy concentration given to the financial market development. Another reason was the denomination of the contract in US dollar, which authorities had justified in terms of attracting foreign participants but failed to do so.

Since 1990 under the new economic policy, regulators obviously became committed to fostering the growth of an effective capital market to support the financial system. Indeed, the government's goal of achieving the status of developed country by the year 2020 meant that a rapidly expanding capital market is essential for funding, and risk management. It also promotes private enterprise by providing a convenient means of raising capital for corporate investment and expansion.

Integral to the growth of capital market is the development of futures market. Futures provide hedging and asset allocation facilities, which allows investors to 
Table 6: Overview of Malaysian commodities contracts

\begin{tabular}{c|l|l|c|c|c|c|c|c}
\hline Year & $\begin{array}{l}\text { Crude } \\
\text { Palm } \\
\text { Oil }\end{array}$ & $\begin{array}{l}\text { RBD Palm } \\
\text { Olein }\end{array}$ & $\begin{array}{l}\text { RSS 1 } \\
\text { Rubber }\end{array}$ & $\begin{array}{l}\text { SMR 20 } \\
\text { Rubber }\end{array}$ & Tin & Cocoa & $\begin{array}{l}\text { Crudc } \\
\text { Palm }\end{array}$ & Kemel oil \\
\hline 1989 & 261871 & - & - & 499 & 10702 & 12016 & - & - \\
1990 & 241984 & 10687 & 20 & 200 & 3133 & 7721 & - & 124 \\
1991 & 320109 & 2240 & - & - & 156 & 2376 & 2721 & - \\
1992 & 255870 & - & - & - & 18 & 519 & - & - \\
\hline
\end{tabular}

Source: Bursa Malaysia website.

hold larger debt and equity positions and, as a result, also enhances the liquidity of these underlying markets. An active futures market that complemented the spot capital market was seen as enabling investors to hedge or adjust their positions and thus make them more willing to take larger holdings, thereby reducing risks of large capital investments.

The stock index futures contract was introduced on the Kuala-Lumpur Option $\&$ Financial Futures Exchange (KLOFFE) on the $15^{\text {th }}$ December 1995 . The contract is recognized as FKLI futures contract which is based on the 100 Kuala-Lumpur composite index (KLCI) stocks. Subsequently the three-month KLIBOR futures (on interest rate) was introduced under the KLOFFE. Due to the lack of coordination between financial futures and commodity futures, KLOFFE and KLCE merged together and became one exchange, which is called Malaysian derivative exchange (MDEX).

Table 7 indicates that introduction of various financial futures and option contracts in Malaysia had also limited success except for the Index futures and CPO futures contracts. One of the possible reasons is that soon after the introduction stock index futures contract experienced serious financial meltdown, which obviously affected the pricing behavior of newly introduced financial futures contracts.

Capital control regulation was introduced to stem the economic meltdown in 1997-8 and also to control the interest rate movement that affected the growth of the financial futures contract. It can be noted that Korean stock index and interest

Table 7: Trading volume of Malaysian financial futures and option contracts

\begin{tabular}{l|l|l|l|c|c|c|c}
\hline Year & $\begin{array}{l}\text { KLCI } \\
\text { Futures }\end{array}$ & $\begin{array}{l}\text { CPO } \\
\text { Futures }\end{array}$ & $\begin{array}{l}\text { KLIBOR } \\
\text { futures }\end{array}$ & $\begin{array}{l}\text { KLCI } \\
\text { option }\end{array}$ & $\begin{array}{l}\text { 5-Year } \\
\text { MGS }\end{array}$ & $\begin{array}{l}\text { 5-Year } \\
\text { MGS }\end{array}$ & $\begin{array}{l}\text { 5-Year } \\
\text { MGS }\end{array}$ \\
\hline 2004 & 1088419 & 1378334 & 141969 & 0 & 19494 & 1799 & 0 \\
2005 & 1111575 & 1068510 & 162592 & 0 & 17215 & 9176 & 0 \\
2006 & 1628043 & 2230340 & 272502 & 0 & 27578 & 1461 & 0 \\
\hline
\end{tabular}

Source: Bursa Malaysia website. 
rate futures were introduced at the same time. However Korean financial futures are considered as one of the highest-ranking financial futures in the world whereas in terms of trading volume, financial futures contract in Malaysia is one of the lowest ranking futures market in the world as well as in the region. The following Table 8 shows the ranking of the futures market in the world and in the region.

\section{Futures and options markets in Japan}

Japan's futures exchanges (commodity products only) date to the 1700s and preceded financial securities markets by nearly a century and a half. This pattern is generally the reverse of that in Europe, England, and the United States, where securities markets usually predated commodity markets. Spot, or cash, trading in rice, the most widely used staple food in Japan, dates from the early 1700s and forward contracting in rice on the Osaka Rice Exchange was legally recognized

Table 8: Asia-Pacific derivatives exchanges ranked by contract volume

\begin{tabular}{l|l|l}
\hline Exchanges & \multicolumn{2}{|l}{ Rank } \\
\hline & World & Regional \\
\hline Karea Stock Exchange & 1 & 1 \\
Tokyo Commodity Exchange & 14 & 2 \\
Dalian Commodity Exchange & 17 & 3 \\
SGX Derivative, Singapore & 22 & 4 \\
Central Japan Commodity Ex. & 23 & 5 \\
Shanghai Futures Exchange & 26 & 6 \\
Zhengzhou Commodity Exchange & 27 & 7 \\
Osaka Securities Exchange & 31 & 8 \\
Taiwan Futures Exchange & 32 & 9 \\
Tokyo Stock Exchange & 35 & 10 \\
Tokyo Grain Exchange & 36 & 11 \\
Korea Futures Exchange & 37 & 12 \\
HK Exchange & 38 & 13 \\
Osaka Mercantile Exchange & 39 & 14 \\
Kansai Commodities Exchange & 41 & 15 \\
Tokyo Intl. Financial Futures Exchange & 44 & 16 \\
Fukuoka Futures Exchange & 46 & 17 \\
Malaysia Derivative Exchange & 51 & 18 \\
Yokohama Commodity Exchange & 52 & 19 \\
\hline Sorce Futus & & \\
\hline
\end{tabular}

Source: Futures Industry Association, Zhengzhou Commodity Exchange and Dalian Commodity Exchange. 
in 1730 . Though there were as many as eight commodity exchanges in major Japanese population centers, the Osaka market was the largest. There were also Japanese markets for edible oils, cotton, and precious metals, though their trading volume was small in comparison with that for rice.

Today there are varieties of commodity futures trading in Tokyo Commodity Exchange, which is well organized, and regulated by the different regulatory authorities. The Tokyo Commodity Exchange (TOCOM) was established on November 1, 1984, as an amalgamation of the Tokyo Textile Exchange, the Tokyo Rubber Exchange and the Tokyo Gold Exchange. Currently Gold futures and options, Silver, Platinum, Palladium, Aluminum, Gasoline, Kerosene, Crude oil, Gas oil and Rubber futures are actively traded in TOCOM. In addition, having successfully launched options on gold futures in May 2004, TOCOM are planning LPG (liquefied petroleum gas) futures.

Since its inception, TOCOM has experienced a remarkable expansion in its market size. TOCOM's trading volume soared from 4 million contracts in 1985 to 87 million contracts in 2003. In terms of trading value, TOCOM is now the world's largest futures market for Platinum, Gasoline and Kerosene.

Various authorities regulate Japanese commodity futures. In Japan, jurisdiction over futures transactions is divided between the Ministry of Finance (bonds and shares), the Ministry of International Trade and Industry (fibers and precious metals), and the Ministry of Agriculture, Forestry and Fisheries (grains). The majority of trading in commodities exchanges in Japan is in precious metals (gold, silver and platinum). The Commodities Exchange Law has been amended 13 times since its enactment in 1950. Major amendments were made in 1967 and 1975. An advisory body to the Ministry of International Trade and Industry came out with a report during 1986 recommending another revision to the law. Revisions were recommended in definitions of objectives, commodities and listing in the law. The revision would also permit the listing of "all things suitable for listing on a commodities future exchange (for example commodity indexes)."

Indeed the Japanese commodity market is dominated by domestic retail investors. The foreign participation is extremely limited in the commodity futures market. In fact, it is the commodity futures markets that account for the bulk of futures trading in Japan. These markets technically are not closed to foreigners, but they operate on such different principles that very few foreign firms wish to participate. Even local institutions shy away from these markets, mainly because they are geared to small-scale speculative trading and lack important customer protections.

The clearest sign of change is at TOCOM, which in 2004-2005 has made extraordinary changes to the ways it operates. For foreign brokers, the most 
important development has been the creation of a true clearinghouse. In the past, TOCOM, like other commodity futures exchanges, processed transactions but did not act as a central counterparty, and every firm that traded on the exchange was therefore exposed to the risk that the other side of the trade would not fulfill its obligations. This was a major hindrance to foreign brokers and commercial users of the exchange.

That changed in June, 2005 when the exchange implemented a new clearinghouse structure and began providing a guarantee on every trade, just as clearinghouses do on European and US futures exchanges. If ever a firm defaulted, the clearinghouse first would seek to cover the firm's obligations out of its margins and what the exchange calls the special deposit for default. If this were not sufficient, the exchange could then turn to its own funds, including a security reserve fund against default that holds 1.23 billion yen ( $\$ 11.5$ million) in 2005 . TOCOM also radically overhauled its technology policy in 2003 and agreed to allow independent software vendors (ISV) to make connections directly to the exchange. "The introduction of ISVs will improve service for overseas clients," according to Chiaka Furui, director of international business derivatives and IT business at Yutaka Shoji, a leading Japanese futures brokerage.

Tocom's changes have created a groundswell of interest, not only within the futures community, but also among traders and brokers as far away as Chicago. Other than TOCOM, Japan has six other commodity futures exchanges, for example Tokyo Grain Exchange, Kansai Agricultural Commodities Exchange (KANEX), Cubu Commodity Exchange and none of them has announced plans to establish a clearinghouse or reach out to the ISV community. Most of these exchanges are geared primarily to the domestic market place, and liquidity comes primarily from retail speculators and brokerage firms trading for their own accounts.

Though commodity futures exchanges are quite large in terms of contract volume, however financial derivatives volumes are relatively lower. Restrictions imposed by regulators, sometimes on the basis of misunderstanding of the impact of derivatives, have tended to keep the financial derivatives market small. Securities firms have not been able to promote derivative products to the mass retail market. The institutional fragmentation of the market has probably not helped its development. Table 9 shows the statistics on Japanese futures and option contracts. Only TOPIX futures trading volume increased substantially (over 300 percent) over 10 years period (from 1997 to 2006). Whereas TOPIX option, Equity option and Government bond futures increased very little over 10 year's period.

The government has launched a modernization plan for both the commodity and financial futures markets. One of the catalysts for this initiative is the recognition by the government and the futures industry that the current structure will not sustain. The legal structure governing commodity futures trading is being 
Table 9: Trading activities for futures and option contract, 1997-2006 (Yen Million)

\begin{tabular}{l|l|l|l|l|l|l|l|l}
\hline Year & \multicolumn{3}{|l|}{ TOPIX Futures } & \multicolumn{2}{l|}{ TOPLX Options } & \multicolumn{2}{l|}{ Equity Options } & \multicolumn{2}{l}{ Govt. Bond Futures } \\
\hline & Vol. & Value & Vol. & Value & Vol. & Value & Vol. & Value \\
\hline 1997 & $3,035,724$ & 421,739 & 9,356 & 2,639 & 70,896 & 3,524 & $11,994,163$ & $15,167,356$ \\
1998 & $2,726,985$ & 320,732 & 655 & 175 & 81,960 & 2,006 & $10,980,296$ & $14,614,854$ \\
1999 & $3,157,441$ & 440,467 & 2,030 & 603 & 212,447 & 8,832 & $9,839,830$ & $12,938,328$ \\
2000 & $4,148,776$ & 642,434 & 2,630 & 1,008 & 380,846 & 25,976 & $10,021,353$ & $13,270,575$ \\
2001 & $5,071,946$ & 590,420 & 7,625 & 3,756 & 392,151 & 11,488 & $7,379,839$ & $10,264,832$ \\
2002 & $7,131,178$ & 699,021 & 93,249 & 23,551 & 304,267 & 4,468 & $6,356,651$ & $8,850,509$ \\
2003 & $9,359,047$ & 861,928 & 98,137 & 13,912 & 296,574 & 2,088 & $6,465,073$ & $9,081,077$ \\
2004 & $10,305,017$ & $1,158,747$ & 17,643 & 6,863 & 174,482 & 3,904 & $8,025,268$ & $11,034,752$ \\
2005 & $12,785,962$ & $1,674,596$ & 20,004 & 17,338 & 201,798 & 3,653 & $9,844,617$ & $13,662,872$ \\
2006 & $14,907,723$ & $2,414,035$ & 18,354 & 13,544 & 190,876 & 2,431 & $12,049,979$ & $16,159,033$ \\
\hline
\end{tabular}

Source: Tokyo Stock Exchange and Tokyo International Financial Futures Exchange. 1USD = 110 Yen in 2006.

aligned closer to global standards. At the end of 2004, fixed commission rates expired. This is widely expected to cause a drastic reduction in revenues for Japanese brokers. Commission rates could fall by more than 50 percent. As a result, the competition among the brokers will be fierce, and it will be survival of the fittest. So there will be a need for strict compliance and surveillance under the new legal environment in order to make sure that the competition is fair.

\section{Futures and derivative market in Singapore}

Due to its strategic location and well-developed infrastructure, Singapore traditionally had been the trade and financial services centre servicing a everincreasing stretch in the region. The country's rapid development was closely linked to the government's efficient financial management. Conservative fiscal and monetary policies generated high savings, which, along with high levels of foreign investment, allowed growth without the accumulation of external debt.

In the 1970s, the government identified financial services as a key source of growth and provided incentives for its development: it has paid of by growing the financial sector as provider of some 25 percent of the GDP today compared to its share of 5 percent some 30 years ago. By the 1980s, the focus was on further diversification, upgrading, and automation of financial services. Emphasis was placed on the development of private investment portfolio management, securities trading, capital market activities, foreign exchange and futures trading, and promotion of more sophisticated and specialized fee-based activities.

Consequently, by the mid-1980s, it was the third most important financial center in Asia after Tokyo and Hong Kong. The financial services sector, having sustained double digit growth over the previous decades, accounted for some 23 percent of GDP and employed approximately 9 percent of the labor force. 
Inaugurated in 1973, the Stock Exchange of Singapore was governed by a committee comprising four elected stockbroker members and five appointed nonbroker members. In late 1988, the 327 companies listed on the main board of the exchange were classified into six groups: industrial and commercial, finance, hotel, property, plantation (farming), and mining.

The exchange underwent a major, prolonged reorganization following the December 1985 collapse of a Singaporean company, Pan Electric, which revealed a massive web of forward share dealings based on borrowed money. The collapse resulted in a tighter regulation of the financial futures market and the securities industry. In 1986 the Securities Industry Council was established to advise the minister for finance on all matters relating to the securities industry. The exchange is now called Sinogapore Exchange, and it is demutualised.

Singapore also expanded other international financial markets in the late 1980s. Trading in gold futures originally was undertaken in the Gold Exchange of Singapore, which was established in 1978 and reorganized in 1983. The scope of its activities was widened to include financial futures trading, and it was renamed the Singapore International Monetary Exchange (SIMEX). Starting in 1984, the financial futures market secured a mutual offset arrangement between SIMEX and the Chicago Mercantile Exchange, which allowed contracts executed on one exchange to be offset on the other without additional transactional cost for market participants. It was a smart move that helped establish a fast expanding futures market henceforth.

The linkage was the first of its kind in the world and greatly facilitated roundthe-clock trading in futures contracts. In 1988 six futures contracts were traded: international gold futures; the Eurodollar time deposit interest rate; the Nikkei

Table 10: Trading activities for futures and derivatives, 1990-2006 (Units)

\begin{tabular}{l|c|c|c|c}
\hline Year & \multicolumn{2}{|c|}{ Volume } & \multicolumn{2}{c}{ Open Interest } \\
\hline & Futures & Options & Futures & Options \\
\hline 1990 & $5,645,430$ & 75,180 & 58,120 & 8,911 \\
1991 & $5,981,380$ & 86,664 & 125,911 & 4,932 \\
1992 & $11,818,786$ & 361,388 & 204,155 & 51,378 \\
1993 & $14,768,322$ & 961,465 & 356,585 & 135,112 \\
1994 & $22,383,719$ & $1,676,555$ & 523,629 & 226,347 \\
1995 & $22,135,821$ & $2,115,518$ & 429,660 & 169,270 \\
1996 & $21,751,494$ & 817,051 & 539,587 & 111,382 \\
1997 & $22,953,892$ & $1,136,393$ & 683,617 & 178,199 \\
1998 & $26,337,972$ & $1,523,190$ & 556,454 & 132,414 \\
1999 & $24,480,004$ & $1,383,136$ & 662,711 & 176,873 \\
2000 & $26,804,964$ & 766,999 & 639,966 & 63,963 \\
2001 & $30,606,546$ & 383,316 & 577,629 & 23,818 \\
2002 & $32,623,190$ & 264,205 & 531,021 & 31,483 \\
2003 & $35,356,776$ & 291,448 & 620,332 & 30,374 \\
2004 & $28,169,379$ & 249,378 & 786,983 & 15,636 \\
2005 & $25,967,661$ & 158,467 & 854,634 & 27,620 \\
\hline
\end{tabular}

Source: Singapore Exchange. 
Average Stock Index; and three currency exchange rates on US dollar/West German deutsche mark, the US dollar/Japanese yen, and the US dollar/British pound sterling. Trading volume on the SIMEX had grown steadily.

Table 10 shows the average volume of trade for 16 financial contracts traded in SIMEX, and now in the Singapore Exchange. From the 16 futures contracts, four contracts, namely, Nikki 225 futures, MSCI Taiwan Index futures, MSCI Singapore futures and Euroyen LIBOR futures are the most successful in terms of volume of trade. Note that these contracts are risk management tools for foreign investors, and are speculative instruments for others. The trading volume of all futures contracts increased from 5.6 million units in 1990 to 26 million units in 2005: a five-fold increase. Trading volume of options increased only from 75,180 units in 1997 to 158,467 units in 2005: a two-fold increase. However, during the 1997-1999 periods, the volume of trade was high indicating hedging activities during the Asian financial crisis period.

\section{Conclusion and policy discussion}

Thus technology, as it has throughout the history of man, has dictated once again the fundamental and revolutionary change in our social structure and reshaped both the political and economic landscape of our planet. Although it is impossible to completely perceive the ultimate consequences of this technological march around us, we know with certainty that its influence to date has been felt nowhere more than in financial markets. Our separate financial existence has been transformed into one inter-related, interdependent world economy. This globalization of markets did not happen overnight.

The first decisive action by financial markets occurred two-and-a-half decades ago with the suspension of dollar convertibility into gold and the abandonment of the system of fixed exchange rates. Globalization and implementation of WTO agreements provide numerous advantages to emerging markets; however, it increases volatility and uncertainty of commodity prices as well as prices of financial instruments. The creation of a global market has made the risk of a contagion and systemic failures much more likely. Therefore development of well-organized derivative market (commodity as well as financial derivatives) is an important policy issue for an emerging market. This policy issue can be divided into two parts: policy for commodity derivative market and policy for financial derivative market.

Commodity derivative exchanges are, and have been very important institutions in commodity pricing and have been prominent in the developed countries including Japan for over a century or more. In Europe and Asia too, commodity derivatives are booming. Price volatility for raw materials has increased for many reasons including the recent changes within the Common Agricultural Policy of the European Union and the WTO which have increased 
price risks for both the primary producers and the processing industry as well.

On the other hand, most of Asian emerging countries are transforming their agriculture-based economies to industrial based economies. However, still agricultural production is contributing a significant portion to GDP. Therefore Asian emerging markets require agricultural commodity futures contract (based on the leading commodity a particular country produces, for example, Copra in Philippine, Oil Palm in Malaysia and so forth) at the same time they also require different raw industrial materials futures market in countries with industry dominance. But it is very costly for Asian emerging countries to introduce many commodity futures contracts. Liquidity constraint, lack of regulatory framework and financial constraints are seen to be most prominent problems. Therefore, in that situation, Japan, Singapore and Hong-Kong can be seen as a common commodity derivative market in which other emerging countries can participate. For example, Japan commodity futures exchanges provide a wide range of commodity futures (from gold futures to energy futures).

According to the Himawari's Mogi (Japanese brokerage house through which foreign customer can participate in the Japanese commodity futures market), "All over Asia we are seeing increasing reliance on the market to set prices for commodities". China has foreign currency issues, Singapore does not have enough liquidity in its commodity futures contracts, and Korea only has securities futures. So Japan is really the best place for hedging commodity risk in the Asian time zone.

The region's financial derivatives have checkered experience in performance, given the dominance of speculators and the small size of the economies to truly reduce the transaction costs. Most of the Asia-pacific equity markets are reasonably well developed. Asian trading venues have undergone multiple layers of transformation in the past decade and will continue to evolve as the world compresses trades through technological innovation. General market liberalization, conflicting regulatory requirements, broker consortiums, and electronic communication networks have all played their parts in Asia changing the trading scene.

Whereas market volatility remains high in Asia, but the opportunities for diversification and risk management opportunities are good if there are futures markets that are efficient with liquidity. Therefore equity based financial futures and option markets must be developed in this region. Some financial derivatives exchanges in the region have shown outstanding growth, for example, Singapore, South Korea, Hong Kong, and Japan. Study of their success does reveal one obvious factor that can be applied universally: the contracts must be relevant to the economy!

From this review of regional experience, it seems that by far the most important success factor for a financial futures and option is liquidity. Malaysian index futures and Hong-Kong financial futures are examples of the liquidity problem due to the government policy shift during several crises. However the 
secondary market for other financial instrument, for example, government bond market, corporate bond market, warrant market, options, etc. are not well developed in Asia's emerging countries. Therefore security commissions and other government agencies should give more attention to develop the secondary markets in other than equity by diversifying into debt, etc. markets before the introduction futures market. Advice to form common markets with larger economies would provide the liquidity lacking in smaller economies.

Acknowledgment: We wish to thank the Journal's Editors for suggestions for changes, which are incorporated in this published version of a paper submitted to the Journal for review. All remaining errors are the responsibility of the authors.

Author statement: The authors are respectively professor and senior lecturer in the Department of Accounting and Finance, University Putra Malaysia, Serdang, Selangor, Malaysia. Both authors' research interests span capital market studies as well as studies of banking institutions in Malaysia.

\section{Reference}

Aggarwal, R., (2001). "Integrating Emerging Market Countries into the Global Financial System: Regulatory Infrastructure Covering Financial Markets." Prepared for the Brookings-Wharton Papers on Financial Services: 4th Annual Conference, January 11-12, 2001, The Brookings Institution, Washington, D.C. Alexander Balfour. February (1995). "Bogged-down in Bombay." Euromoney. Issue 310. p. 96.

Berkman, H., and Eleswarapu, V.R., (1998). "Short Term Trader and Liquidity:A Test Using Bombay Stock Exchange Data", Journal of Finance Economics 47: 339-355.

Joost M.E. Pennings, J M.E and Meulenberg, M.T.G. (1999), “The Financial Industry's Challenge of Developing Commodity Derivatives," OFOR Paper Number 99-01, May 1999.

Mansingh L., (2004). "Volume of Commodity Futures Trading to Overtake Stock Market Trade Volumes". Keynotes Speech at Seminar Jointly Organized by FICCI (Federation of Indian Chamber of Commerce) and NCDEX (National Commodity \& Derivatives Exchange Ltd).

Melamed, L., (1994). "Derivatives and the Asian Market", International Futures Seminar Seoul, South Korea December 15, 1994

Nair, C.K.G., (2001a). “Market Dynamics and Regulatory Concerns” NSE News, June 2001.

Nair, C.K.G., (2001b). “ Securities Market and Commodity Derivative market "Rush vs Slow Growth", NSE News, December 2001.

Nair, C.K.G., (2004). "Commodity Futures Markets in India: Ready for "Take off'? NSE News, June 2004.

$\mathrm{Ng}$, Beoy Kui, (1987). "An Overview of the Foreign Exchange Markets in the 
SEACEN Countries," SEACEN Centre. Foreign Exchange Markets in the SEACEN Centre. Kuala Lumpur: The South East Asian Central Banks (SEACEN) Research and Training Center.

$\mathrm{Ng}$, Beoy Kui, (1996). "Bank Liquidity Management and the Implementation of Exchange Rate Policy in Singapore," in Lim Chong Yah (ed.), Economic Policy and Management in Singapore, Singapore: Addison-Wesley publishing Co., pp 253-274.

Ng, Beoy Kui, (1996). "The Role of the Central Provident Fund in Social Development, Stabilization and Restructuring: Experience from Singapore," in New Zealand Journal of Business 18 (no.1): 39-51.

Ramaswami, B, Ravi S. and Chopra S.D (2003). "Risk Management in Agriculture", Discussion in Economics (03-08), Indian Statistical Institute, Delhi, Planning Unit.

Sahadevan K.G., (2002). "Derivative and Price Risk Management; A study of Agricultural Commodity Futures in India”, Institute of Management, Lucknow.

Susan, T (2003), “Agricultural Commodity Markets in India; Policy Issues for Growth," Indira Gandhi Institute for Development Research, Mumbai.

Wu, Friedrich, (1997). "Hong Kong and Singapore: A Tale of Two Asian Business Hubs," Journal of Asian Business 13 (no. 2). 